p-ISSN: 1410-0029; e-ISSN2549-6786

Agrin Vol. 24, No. 1, April 2020

\title{
PENGARUH LAMA PEMANASAN BASAH DAN PERENDAMAN DALAM GIBERELIN TERHADAP PEMATAHAN DORMANSI BENIH KELAPA SAWIT (Elaeis guineensis Jacq.)
}

\section{Effect of Wet Heating Time and Immersion in Gibberellins on Breaking of Oil Palm Seed Dormancy (Elaeis guineensis jacq.)}

\author{
Agustiansyah $^{1 *}$, Ardian$^{2}$, Kukuh Setiawan', dan Erni Permata Dewi \\ ${ }^{1}$ Jurusan Agronomi dan Hortikultura, Fakultas Pertanian Universitas Lampung \\ ${ }^{2}$ Jurusan Agroteknologi, Fakultas Pertanian Universitas Lampung \\ ${ }^{3}$ Alumni Program Studi Agroteknologi, Fakultas Pertanian Universitas Lampung
}

Alamat Korespondensi: agustiansyah.1972@fp.unila.ac.id

\begin{abstract}
ABSTRAK
Penelitian ini bertujuan mengetahui pengaruh pemanasan basah dalam perkecambahan benih kelapa sawit yang dikombinasikan dengan perendaman dalam giberelin. Perlakuan disusun secara faktorial dengan dua faktor dalam Rancangan Acak Lengkap. Faktor pertama adalah lama pemanasan basah pada suhu $40^{\circ} \mathrm{C}$ yang terdiri atas lima taraf yaitu (1) 20 hari pemanasan, (2) 25 hari pemanasan, (3) 30 hari pemanasan, (4) 35 hari pemanasan, dan (5) 40 hari pemanasan. Faktor kedua adalah konsentrasi giberelin dalam empat taraf yaitu (1) $0 \mathrm{ppm}$; (2) $100 \mathrm{ppm}$; (3) $200 \mathrm{ppm}$ dan (4) $300 \mathrm{ppm}$. Benih dalam kondisi basah (kadar air $\pm 25 \%$ ) dimasukkan ke dalam plastik bening yang tahan panas, diikat kuat dengan tali rafia. Benih disusun dalam oven pada suhu $40^{\circ} \mathrm{C}$ sesuai perlakuan, yaitu selama 20 hari, 25 hari, 30 hari, 35 hari, dan 40 hari. Selanjutnya dilakukan perendaman dengan larutan giberelin $\left(\mathrm{GA}_{3}\right)$ selama 3 hari sesuai perlakuan, yaitu pada konsentrasi 0 ppm, $100 \mathrm{ppm}, 200 \mathrm{ppm}$, dan $300 \mathrm{ppm}$. Benih dikecambahkan dengan uji kertas digulung didirikan dalam plastik (UKDdp). Variabel yang diamati adalah persentase berkecambah benih, potensi tumbuh maksimum, kecepatan perkecambahan, waktu munculnya radikula, dan kandungan giberelin endogen benih. Hasil penelitian menunjukkan bahwa pemanasan basah dapat meningkatkan persentase berkecambah, potensi tumbuh maksimum, kecepatan perkecambahan, dan waktu munculnya kecambah. Perlakuan pemanasan 30 hari + perendaman dalam giberelin 200 ppm merupakan perlakuan terbaik dalam menghasilkan persentase perkecambahan $(64 \% \pm 1.3)$, potensi tumbuh maksimum $(72.0 \% \pm 1.1)$, dan kecepatan pertumbuhan $(29 \% \pm 1.0$ per etmal).
\end{abstract}

Kata kunci: benih, kelapa sawit, pemanasan basah, giberelin

\section{ABSTRACT}

The aims of this research to determined the effect of wet heating and immersion in gibberellins on breaking dormancy of oil palm seed. The treatments were arranged in factorially with two factors in the Completely Randomized Design. The first factors was wet heating $\left(40^{\circ} \mathrm{C}\right)$ which consists of five levels, (1) 20 days of heating; (2) 25 days of heating (3) 30days of heating (4) 35 days of heating (5) 40 days of heating. The second factor was the concentrations of gibberellin in four levels, (1) 0 ppm; (2) $100 \mathrm{ppm}$; (3) $200 \mathrm{ppm}$ and (4) $300 \mathrm{ppm}$. The observed variables were percentage of seed germination, maximum growth potential, speed of germination, time of radicle emergence, and content of endogenous gibberellins in seeds. The results showed that wet heating could increased the percentage of germination, maximum growth potential, speed of germination, and time of emergence of sprouts. The 30 days wet heating treatment + immersion in 200 ppm giberelin was the best treatment in percentage of germination (64\% 1.3$)$, maximum growth potential $(72.0 \% \pm 1.1)$, and speed of germination $(29 \% \pm 1.0$ per etmal).

Keywords: Seed, oil palm, wet heating, giberellin

\section{PENDAHULUAN}

Benih kelapa sawit merupakan salah satu benih famili palem yang memerlukan waktu relatif lama untuk berkecambah dengan persentase berkecambah yang rendah dan tidak seragam (Martine et al., 
2011; Nazario et al., 2013; Sudsiri et al., 2016; Groot, 2020). Hal ini disebabkan benih famili palem termasuk kelapa sawit mengalami dormansi morfo-fisiologis (Baskin dan Baskin, 2014; Norsazwan, 2016).

Metode pemanasan kering (dry heat treatment) telah lama diterapkan untuk mematahkan dormansi benih kelapa sawit. Metode ini dilakukan dengan mengoven benih selama 50-80 hari pada suhu $40^{\circ} \mathrm{C}$ (Fondom et al., 2010; Green et al., 2013; Nuraini et al., 2016; Tabi et al., 2017). Metode penggunaan bahan kimia dengan asam klorida (Aryani dan Suzanna, 2014), hidrogen sianamida (Jimenez et al., 2008), hidrogen peroksida (Martine et al., 2011) untuk menggantikan pemanasan kering juga telah dilakukan.

Zat pengatur tumbuh tanaman juga telah digunakan untuk meningkatkan perkecambahan benih termasuk benih kelapa sawit, konsentrasi giberelin 100 dan 200 ppm berpengaruh baik pada variabel persentase perkecambahan, indeks vigor, panjang radikula dan panjang plumula (Nuraini et al., 2016; Tabi et al., 2017). Metode tersebut mampu meningkatkan perkecambahan, namun masih membutuhkan waktu perkecambahan yang relatif lama yaitu 60-90 hari.

Benih tanaman termasuk benih kelapa sawit memiliki kandungan zat pengatur tumbuh termasuk giberelin (Tuan et al.,
2018; Kwon et al., 2020), ABA (Tuan et al., 2018), dan sitokinin (Widajati et al., 2012). Pada proses perkecambahan benih, faktor suhu, zat pengatur tumbuh, dan air sangat berperan dalam proses imbibisi. Oleh karena itu keberadaan air dalam proses pemanasan sangat penting dalam pemecahan dormansi benih kelapa sawit. Penelitian ini bertujuan mengetahui pengaruh pemanasan basah dalam perkecambahan benih kelapa sawit yang dikombinasikan dengan peredaman dalam giberelin.

\section{METODE PENELITIAN}

Penelitian ini dilakukan di Laboratorium Benih dan Pemuliaan Tanaman, Fakultas Pertanian, Universitas Lampung, dari bulan September 2018 Maret 2019.

Penelitian ini menggunakan Rancangan Acak Lengkap (RAL). Perlakuan yang diuji merupakan kombinasi lama pemanasan basah dan konsentrasi giberelin. Lama pemanasan basah pada suhu $40^{\circ} \mathrm{C}$ yang terdiri atas lima taraf yaitu: (1) 20 hari pemanasan; (2) 25 hari pemanasan; (3) 30 hari pemanasan; (4) 35 hari pemanasan dan (5) 40 hari pemanasan. Konsentrasi giberelin yang diuji yaitu: (1) 0 ppm; (2)100 ppm; (3) 200 ppm dan (4) 300 ppm. Sehingga terdapat 20 kombinasi perlakuan dan diulang tiga kali. Setiap ulangan terdiri dari tiga gulungan benih 
yang masing-masing berisi lima butir benih yang diuji dengan metode uji kertas digulung didirikan dalam plastik (UKDdp). Perbedaan pola perkecambahan atau perbedaan nilai tengah antar perlakuan dianalisis dengan pengujian standar deviasi.

Penelitian dilakukan mengikuti tahapan sebagai berikut.

\section{Persiapan benih}

Benih diambil dari pohon kelapa sawit varietas Dura yang cukup dewasa dengan umur $>5$ tahun. Benih yang digunakan adalah benih yang telah masak fisiologis yaitu dari tandan buah berumur 140 hari setelah polinasi dengan ciri-ciri berwarna kuning ke-orange-an. Kemudian benih direndam dengan air selama 7 hari sampai kadar air mencapai $\pm 25 \%$ (Tamrin et al., 2017). Selanjutnya buah dikupas kulitnya untuk mendapatkan benih tanpa sabut dan dicuci hingga bersih. Benih yang telah dikupas dan dicuci, diseleksi untuk mendapatkan benih yang seragam.

2. Pemanasan basah

Benih dalam kondisi basah dimasukkan ke dalam plastik bening yang tahan panas, diikat kuat dengan tali rafia. Kemudian benih disusun dalam oven dan dioven pada suhu $40^{\circ} \mathrm{C}$ sesuai perlakuan, yaitu selama 20 hari, 25 hari, 30 hari, 35 hari, dan 40 hari. Selama pemanasan dilakukan penambahan air (penyemprotan) pada benih agar tidak kering dan menjaga kelembaban.
3. Perendaman dalam larutan giberelin

Benih dikeringanginkan dan dilakukan perendaman dengan larutan giberelin $\left(\mathrm{GA}_{3}\right)$ selama 3 hari sesuai perlakuan (Agustiansyah et al., 2020), yaitu pada konsentrasi 0 ppm, 100 ppm, 200 ppm, dan 300 ppm. Perendaman dilakukan didalam botol kaca yang ditutup dengan plastik dan diikat dengan karet.

4. Pengecambahan

Setelah direndam, benih ditiriskan dan dikecambahkan dengan uji kertas digulung didirikan dalam plastik (UKDdp). Setiap gulungan berisi 5 butir benih. Benih disusun dengan bentuk zig-zag dalam kertas koran putih polos (biasa disebut kertas CD) yang telah dilembabkan sebelumnya (Purbojati dan Suwarno, 2006). Penyusunan zig-zag berfungsi untuk mempermudah penggulungan kertas dikarenakan benih kelapa sawit berukuran besar. Kemudian diletakkan ke dalam germinator. Apabila kertas sudah tidak lembab ataupun kering maka dilakukan penyemprotan dengan air. Pengamatan dilakukan setiap hari dari hari pertama sampai hari ke-60 ( \pm 2 bulan) setelah diletakkan di germinator.

Variabel yang diamati adalah:

1 Persentase berkecambah benih, dihitung dengan rumus:

$D B=\frac{\sum \text { Benih yang berkecambah }}{\sum \text { Benih yang dikecambahkan }} X 100 \%$ 
2 Potensi tumbuh maksimum, nilai potensi tumbuh maksimum dapat diketahui dengan rumus:

$P T M=\frac{\sum \text { Kecambah normal }+\sum \text { Kecambah Abnormal }}{\sum \text { Benih yang dikecambahkan }} X 100 \%$

3 Kecepatan perkecambahan, dihitung dengan rumus:

$K P=\sum_{t=1}^{n} \frac{\left(K N_{(t)}-K N_{(t-1)}\right)}{T}$ atau $K P=\sum_{t=1}^{n} \frac{\Delta K N}{t}$ Keterangan :

$\mathrm{t}=$ jumlah hari atau jumlah etmal sejak penanaman benih hingga hari pengamatan ke $\mathrm{t}(\mathrm{t}=1,2$, ...,n), dan satu etmal adalah jumlah waktu 24 jam.

$\mathrm{KN}=$ persen kecambah normal, $\Delta$

$$
\mathrm{KN}=\mathrm{KN}_{(\mathrm{t})}-\mathrm{KN}_{(\mathrm{t}-1)} \text {. }
$$

(4) Waktu munculnya radikula, diketahui dengan mengamati setiap hari untuk melihat munculnya radikula yang keluar dari poros embrio.

(5) Kandungan giberelin endogen benih diuji setelah benih dipanaskan 20, 25, 30, 35, dan 40 hari. Kandungan giberelin endogen dianalisis dengan HPLC (Sedayu et al, 2013).

\section{HASIL DAN PEMBAHASAN}

\section{Persentase Berkecambah Benih}

Berdasarkan hasil percobaan menunjukkan bahwa perlakuan kombinasi lama pemanasan basah dan perendaman dalam giberelin berpengaruh baik pada persentase daya berkecambah benih kelapa sawit. Pada lama pemanasan basah 20, 25, 35 hari, persentase berkecambah benih tanpa perendaman dalam giberelin lebih tinggi dibandingkan dengan perendaman dalam giberelin yaitu $62.9 \% \pm 1.3 ; 60.0 \% \pm$ $1.3 ; 58.3 \% \pm 1.3$. Persentase berkecambah benih tertinggi didapat pada pemanasan 30 hari + perendaman dalam giberelin 200 ppm yaitu $64 \% \pm 1.3$. Hasil tersebut tidak bebeda dengan pemanasan basah tanpa direndam dalam giberelin. Persentase berkecambah benih terendah terjadi pada pemanasan 40 hari, baik dengan maupun tanpa perendaman dalam giberelin (Gambar 1).

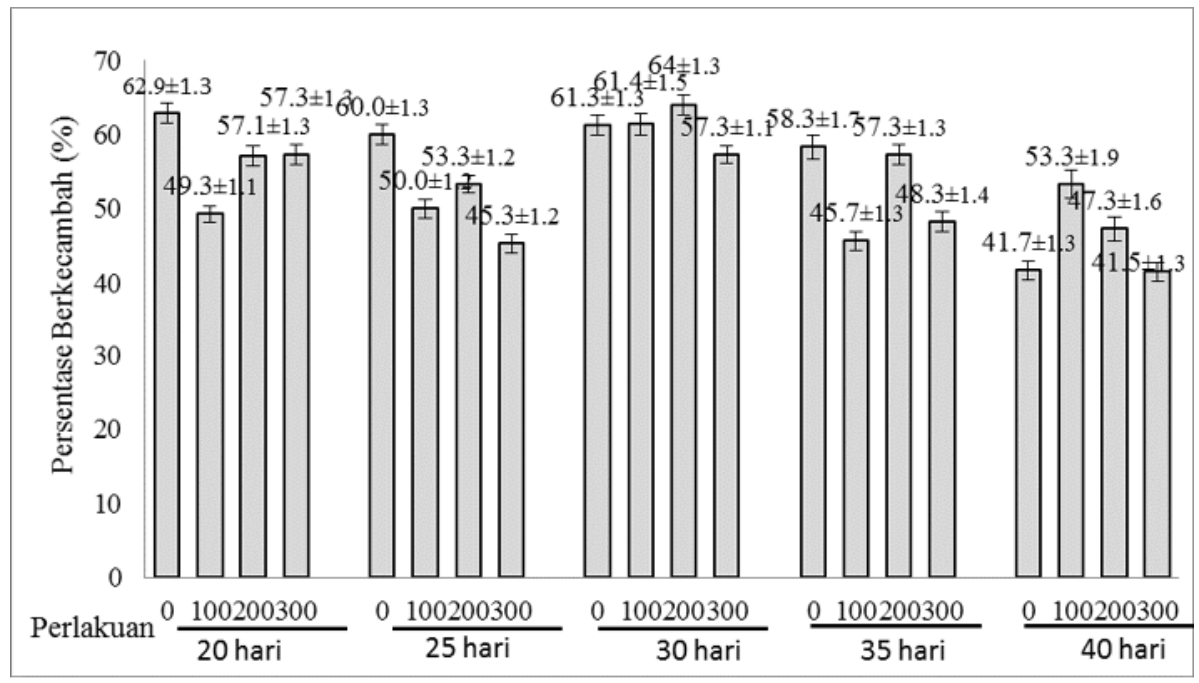

Gambar 1. Persentase daya berkecambah benih sawit setelah pemanasan basah dan perendaman dalam giberelin. Keterangan: angka 20, 25, 30, 35, 40 adalah lama pemanasan basah (hari); angka 100, 200, 300 adalah konsentrasi giberelin (ppm). 


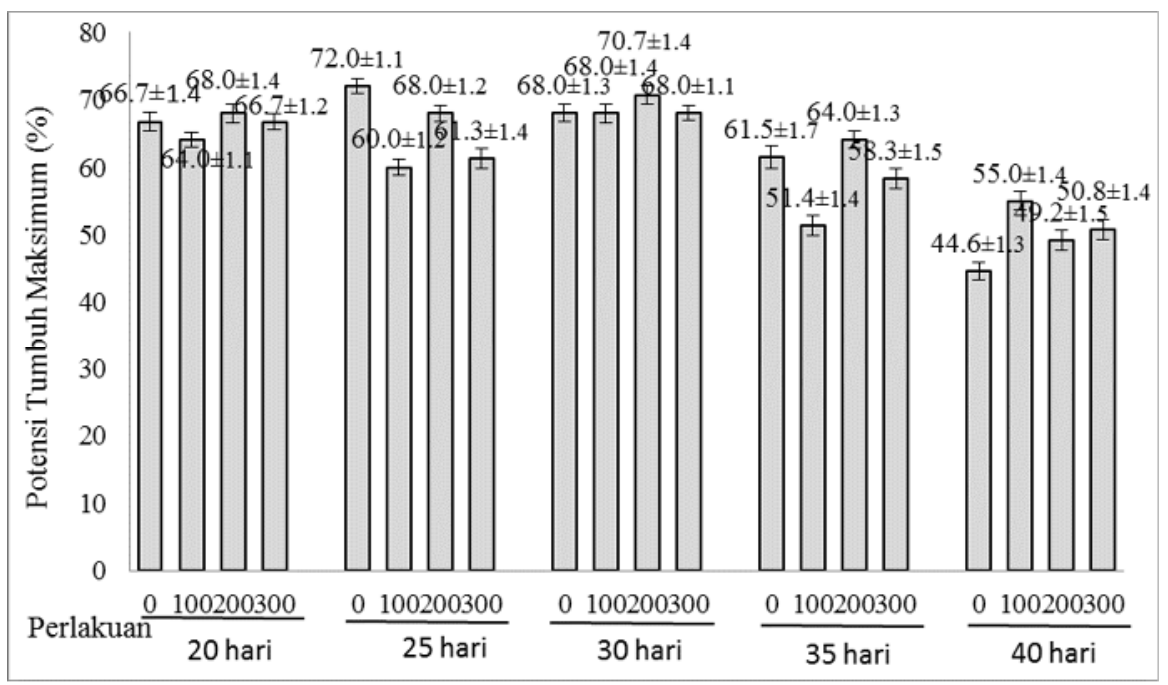

Gambar 2. Potensi tumbuh maksimum benih kelapa sawit setelah pemanasan basah dan perendaman dalam giberelin. Keterangan: angka 20, 25, 30, 35, 40 adalah lama pemanasan basah (hari); angka 100, 200, 300 adalah konsentrasi giberelin (ppm).

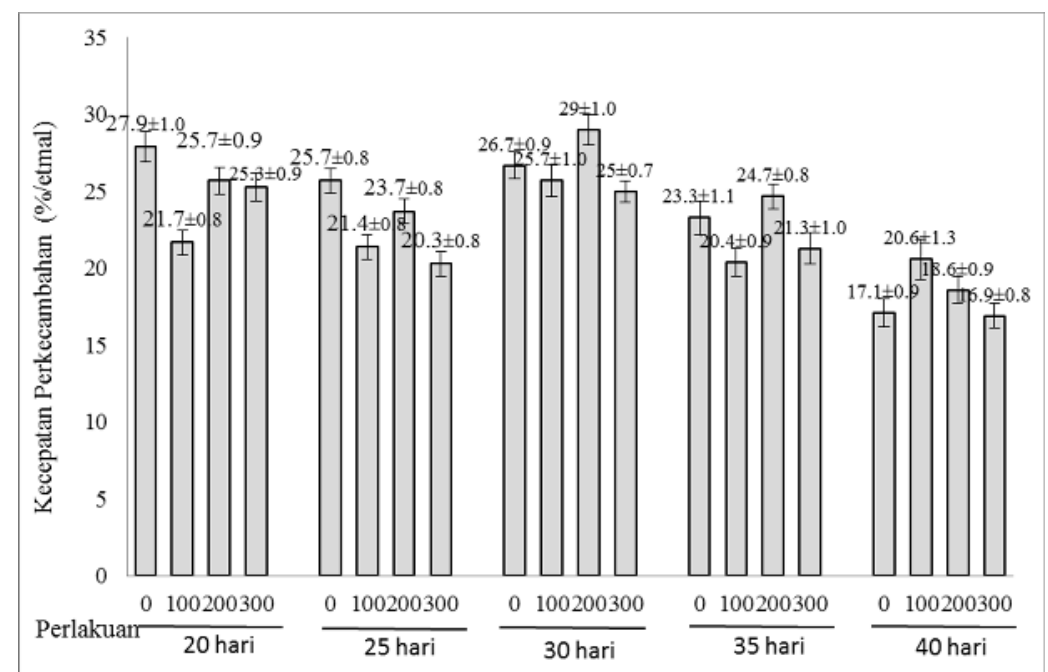

Gambar 3. Kecepatan berkecaambah benih kelapa sawit setelah pemanasan basah dan perendaman dalam giberelin. Keterangan: angka 20, 25, 30, 35, 40 adalah lama pemanasan basah (hari); angka 100, 200, 300 adalah konsentrasi giberelin (ppm).

\section{Potensi Tumbuh Maksimum}

Kombinasi perlakuan lama pemanasan basah dan perendaman dalam giberelin berpengaruh baik pada persentase daya berkecambah benih kelapa sawit. Terdapat delapan belas (18) perlakuan dari dua puluh (20) perlakuan yang menghasilkan potensi tumbuh maksimum di atas 50\%. Potensi tumbuh maksimum tertinggi $(72.0 \% \pm .1 .1)$ dihasilkan pada perlakuan pemanasan basah 25 hari tanpa perendaman di dalam giberelin, tidak berbeda dengan perlakuan pemanasan 30 hari dan direndam dalam giberelin $200 \mathrm{ppm}$ yaitu $70.7 \% \pm 1.4$. Pada variabel ini juga didapatkan hasil penting yaitu, pemanasan basah 20, 25, 30, dan 35 hari menghasilkan pemanasan basah tanpa perendaman dalam 
giberelin relatif sama dengan perendaman dalam giberelin, bahkan lebih tinggi tanpa perendaman dalam giberelin. Pada pemanasan 40 hari, potensi tumbuh maksismum benih cenderung lebih rendah dari pemanasan 20, 25, 30, dan 35. Tanpa perendaman dalam giberelin menhasilkan potensi tumbuh maksimum terendah yaitu $44.6 \% \pm 1.3$ (Gambar 2).

\section{Kecepatan Perkecambahan Benih}

Pemanasan basah dapat meningkatkan kecepatan perkecambahan benih kelapa sawit. Pada pemanasan 20, 25, 30, dan 35 hari, pemanasan basah tanpa perendaman dalam giberelin dapat meningkatkan kecepatan perkecambahan dibandingkan pemanasan 40 hari. Lama pemanasan 40 hari adalah lama pemanasan yang umum dilakukan dalam pemecahan dormansi kelapa sawit namun dalam kondisi pemanasan kering (dry heat treatment). Perlakuan pemanasan basah 30 hari + perendaman dalam giberelin 200 menghasilkan kecepatan perkecambahan tertinggi yaitu $29 \% \pm 1.0$ per etmal berbeda nyata dengan perlakuan lainnya kecuali dengan perlakuan pemanasan 20 hari tanpa perendaman dalam giberelin. Perlakuan pemanasan 40 hari tanpa perendaman dalam giberelin dan konsentrasi giberelin 200 dan 300 ppm menghasilkan kecepatan terendah dibandingkan perlakuan lainnya (Gambar 3).

\section{Waktu Munculnya Kecambah (Radikula)}

Pemanasan basah di dalam oven selama 30 dan 35 hari dapat mempercepat munculnya radikula, muncul tercepat pada hari ke-4 pengecambahan. Sehingga munculnya kecambah membutuhkan waktu 34 hari (30 hari oven +4 hari kecambah) dengan persentase perkecambahan 1.3\% pada konsentrasi giberelin 300 ppm. Pada hari ke-14 pengecambahan merupakan waktu tercepat dan serempak munculnya radikula untuk semua perlakuan (Tabel 1).

\section{Kandungan Giberelin pada Benih}

Berdasarkan hasil analisis, kandungan giberelin endogen setelah pemanasan tertinggi didapat pada perlakuan 20 hari pemanasan $35.81 \mathrm{ppm}$, terendah pada pemanasan 40 hari sebesar 18 ppm. Pemanasan 25, 30, dan 35 hari pemanasan memiliki kandungan giberelin endogen yang relatif sama yaitu masing-masing sebesar 24.40 ppm; 26.64 ppm; dan 25.52 ppm (Tabel 2).

Perlakuan lama pemanasan basah dapat meningkatkan dan mempercepat retaknya operculum pada benih jika dibandingkan dengan pemanasan kering (dry heat treatment) yang umum dilakukan pada pemecahan dormansi benih kelapa sawit. Retaknya operculum menyebabkan terjadinya imbibisi sehingga proses metabolisme dapat berjalan lebih cepat. Lebih cepat retaknya operculum dapat 
dilihat pada persentase perkecambahan, potensi tumbuh maksimum, kecepatan perkecambahan, dan waktu (hari) munculnya kecambah (Gambar 1, 2, 3, dan Tabel 1). Persentase berkecambah benih tertinggi didapat pada pemanasan 30 hari + perendaman dalam giberelin $200 \mathrm{ppm}$ yaitu $64 \% \pm 1.3$ (Gambar 1). Radikula muncul

Tabel 1. Pengaruh periode pemanasan dan konsentrasi giberelin terhadap waktu munculnya berkecambah benih kelapa sawit (data ditampilkan \pm 1bulan pengamatan)

\begin{tabular}{|c|c|c|c|c|c|c|c|c|c|c|c|c|}
\hline \multirow{3}{*}{$\frac{\text { Perlakuan }}{20 \text { hari, } 0 \text { ppm }}$} & \multicolumn{12}{|c|}{ Waktu munculnya kecambah pada hari ke- pengamatan (\%) } \\
\hline & \multicolumn{3}{|c|}{4} & \multicolumn{3}{|c|}{14} & \multicolumn{3}{|c|}{24} & \multicolumn{3}{|c|}{34} \\
\hline & 0,0 & \pm & 0,0 & 6,7 & \pm & 0,8 & 25,3 & \pm & 1,2 & 37,3 & \pm & 1,3 \\
\hline 20 hari, $100 \mathrm{ppm}$ & 0,0 & \pm & 0,0 & 8,0 & \pm & 0,9 & 21,3 & \pm & 1,1 & 36,0 & \pm & 1,2 \\
\hline 20 hari, $200 \mathrm{ppm}$ & 0,0 & \pm & 0,0 & 9,3 & \pm & 1,0 & 28,0 & \pm & 1,3 & 42,7 & \pm & 1,2 \\
\hline 20 hari, $300 \mathrm{ppm}$ & 0,0 & \pm & 0,0 & 16,0 & \pm & 0,9 & 25,3 & \pm & 1,0 & 38,7 & \pm & 1,2 \\
\hline 25 hari, 0 ppm & 0,0 & \pm & 0,0 & 14,7 & \pm & 1,2 & 33,3 & \pm & 1,3 & 48,0 & \pm & 1,4 \\
\hline 25 hari, $100 \mathrm{ppm}$ & 0,0 & \pm & 0,0 & 12,0 & \pm & 1,0 & 22,7 & \pm & 1,1 & 33,3 & \pm & 1,2 \\
\hline 25 hari, $200 \mathrm{ppm}$ & 0,0 & \pm & 0,0 & 17,3 & \pm & 1,1 & 28,0 & \pm & 1,3 & 44,0 & \pm & 1,2 \\
\hline 25 hari, $300 \mathrm{ppm}$ & 0,0 & \pm & 0,0 & 9,3 & \pm & 0,8 & 30,7 & \pm & 1,1 & 37,3 & \pm & 1,3 \\
\hline 30 hari, 0 ppm & 0,0 & \pm & 0,0 & 25,3 & \pm & 1,2 & 40,0 & \pm & 1,2 & 54,7 & \pm & 1,3 \\
\hline 30 hari, $100 \mathrm{ppm}$ & 0,0 & \pm & 0,0 & 13,3 & \pm & 1,2 & 26,7 & \pm & 1,4 & 42,7 & \pm & 1,6 \\
\hline 30 hari, $200 \mathrm{ppm}$ & 0,0 & \pm & 0,0 & 16,0 & \pm & 1,2 & 30,7 & \pm & 1,3 & 42,7 & \pm & 1,3 \\
\hline 30 hari, $300 \mathrm{ppm}$ & 1,3 & \pm & 0,6 & 18,7 & \pm & 1,3 & 36,0 & \pm & 1,4 & 49,3 & \pm & 1,3 \\
\hline 35 hari, 0 ppm & 0,0 & \pm & 0,0 & 16,9 & \pm & 1,3 & 35,4 & \pm & 1,6 & 47,7 & \pm & 1,8 \\
\hline 35 hari, $100 \mathrm{ppm}$ & 1,4 & \pm & 0,6 & 21,4 & \pm & 1,3 & 35,7 & \pm & 1,4 & 41,4 & \pm & 1,4 \\
\hline 35 hari, $200 \mathrm{ppm}$ & 0,0 & \pm & 0,0 & 20,0 & \pm & 1,1 & 40,0 & \pm & 1,2 & 44,0 & \pm & 1,2 \\
\hline 35 hari, $300 \mathrm{ppm}$ & 0,0 & \pm & 0,0 & 11,7 & \pm & 1,1 & 30,0 & \pm & 1,3 & 43,3 & \pm & 1,4 \\
\hline 40 hari, 0 ppm & 0,0 & \pm & 0,0 & 13,8 & \pm & 1,1 & 32,3 & \pm & 1,4 & 33,8 & \pm & 1,5 \\
\hline 40 hari, $100 \mathrm{ppm}$ & 0,0 & \pm & 0,0 & 6,7 & \pm & 0,9 & 25,0 & \pm & 1,6 & 31,7 & \pm & 1,6 \\
\hline 40 hari, $200 \mathrm{ppm}$ & 0,0 & \pm & 0,0 & 23,1 & \pm & 1,3 & 32,3 & \pm & 1,4 & 40,0 & \pm & 1,4 \\
\hline 40 hari, $300 \mathrm{ppm}$ & 0,0 & \pm & 0,0 & 18,5 & \pm & 1,1 & 33,8 & \pm & 1,3 & 40,0 & \pm & 1,3 \\
\hline
\end{tabular}

Tabel 2. Kandungan giberelin endogen benih kelapa sawit setelah dioven basah

\begin{tabular}{cc}
\hline Lama Pemanasan (hari) & Kandungan giberelin $(\mathrm{ppm})$ \\
\hline 20 & 35,81 \\
25 & 24,40 \\
30 & 26,64 \\
35 & 25,52 \\
40 & 18,00 \\
\hline
\end{tabular}


Norsazwan et al. (2020), fluktuasi suhu tinggi dan rendah dapat meningkatkan kemampuan berkecambah dan kecepatan berkecambah benih sawit. Martins et al. (2003) melaporkan pada benih King palms persentase berkecambahnya lebih dari $67 \%$ pada kadar air 47\% dengan persentase berkecambah kurang dari 52.5\% pada kadar air 31.5\%. Sedangkan menurut Gasselin and Cochard (2005), benih kelapa sawit digolongkan kedalam benih semirekalsitran yang membutuhkan kadar air tinggi untuk dapat berkecambah normal. Selain itu, kadar air yang tinggi pada benih rekalsitran atau semirekalsitran dibutuhkan saat benih disimpan.

Hasil ini lebih baik jika dibandingkan dengan penelitian Nuraini et al. (2016); Fondom et al. (2010) yang membutuhkan waktu 60 hari agar benih kelapa sawit dapat berkecambah dengan metode panas kering. Jimenez et al. (2008) membutuhkan 89 hari dengan metode panas kering dan 67 hari dengan metode perendaman dalam hidrogen sianamida. Hasil penelitian ini juga menunjukkan bahwa pemberian giberelin akan sangat berperan meningkatkan perkecambahan benih sawit (20, 25, 30, 35 hari pemanasan). Namun pada perlakuan pemanasan 40 hari memiliki kandungan giberelin endogen paling rendah yaitu (18 ppm), sehingga secara umum memiliki persentase berkecambah, potensi tumbuh maksimum,dan kecepatan pertumbuhan lebih rendah dibandingkan perlakuan lainnya (Gambar 1, 2, 3). Perendaman dalam giberelin dapat meningkatkan perkecambahan pada benih purwoceng, (Rusmin et al., 2011), mucuna (Astari et al., 2014), loquat (Al-Hawezy, 2013), macaw palm (Oliviera et al., 2013), sirsak (Polhaupessy, 2014).

Pada Tabel 2, kandungan giberelin pada pemanasan 20, 25, 30, dan 35 cukup tinggi sehingga perlakuan perendaman dalam giberelin eksogen menjadi tidak efektif. Kondisi pemanasan basah ini memicu giberelin lebih cepat melakukan proses metabolisme di dalam benih dengan giberelin endogen sebagai pemacu proses metabolime tersebut. Sedangkan pada pemanasan $40^{\circ} \mathrm{C}$, kondisi lebih kering sehingga proses metabolisme berjalan lebih lambat. Jimenez et al. (2008) menyatakan perlakuan panas mengurangi konsentrasi ABA. Tabi et al. (2017), pemanasan menyebabkan rasio giberelin/ABA lebih tinggi sehingga meningkatkan perkecambahan. Giberelin merupakan ZPT yang berperan dalam mengaktifkan enzim $\alpha$ amilase yang berfungsi merombak karbohidrat dan sangat berperan dalam perkecambahan benih (Pan et al., 2017; Ghosh and Halder, 2018).

\section{KESIMPULAN}

Berdasarkan hasil penelitian dapat disimpulkan bahwa (1) Lama pemanasan 
basah 20, 25, 30, dan 35 hari dapat meningkatkan persentase berkecambah, potensi tumbuh maksimum, kecepatan perkecambahan, dan waktu munculnya kecambah, (2) Perlakuan pemanasan 30 hari + perendaman dalam giberelin 200 ppm merupakan perlakuan terbaik dalam menghasilkan persentase perkecambahan $(64 \% \pm 1.3)$, potensi tumbuh maksimum (72.0\%土.1.1), dan kecepatan pertumbuhan $(29 \% \pm 1.0$ per etmal).

\section{DAFTAR PUSTAKA}

Agustiansyah, Ardian, K. Setiawan, D. Rosmala. 2020. Pengaruh lama perendaman dalam berbagai konsentrasi giberelin $\left(\mathrm{GA}_{3}\right)$ terhadap perkecambahan benih kelapa sawit (Elaeis guineensis Jacq.). Jurnal Agrovigor: Jurnal Agroteknologi, 13 (2): 94-99.

Al-Hawezy, S.M.N. 2013. The role of the different concentrations of $\mathrm{GA}_{3}$ on seed germinaton and seedling growth of loquat (Eriobotrya japonica L.). Journal of Agriculture and Veterinary Science, 4(5): 1-6.

Aryani, F. dan E, Suzanna. 2014. Pematahan dormansi benih kelapa sawit dengan perlakuan skarifikasi kimiawi (asam klorida). Jurnal Agroqua, 12 (2): 107-117.

Astari, R.P., Rosmayanti, dan E.S. Bayu. 2014. Pengaruh pematahan dormansi secara fisik dan kimia terhadap kemampuan berkecambah benih mucuna (Mucuna bracteata D.C). Jurnal Agroekoteknologi, 2(2): 803812.

Baskin, J.M \& C.C. Baskin. 2014. What kind of seed dormancy might palm have?. Seed Science Research, 24 (1):17-22.

Fondom, N. Y., C.E. Etta, A.M. Mih. 2010. Breaking seed dormancy: revisiting heat-treatment duration on germination and subsequent seedling growth of oil palm (Elaeis guineensis Jacq.) progenies. Journal of Agricultural Science, 2(2): 101-110.

Gasselin, T.D. and B. Cochard. 2005. Oil palm seed distribution. OCL., 12:148153.

Ghosh, S., Halder, S. 2018. Effect of different kinds of gibberellin on temperate fruits crops: A review. The Pharma Innovation Journal, 7(3): 315-319.

Groot, S.P.C. 2020. Editorial:Seed science and technology. Seed Science and Technology, 48(1): 133-142.

Green, M., W.A.A.Lima, A.F. de Figueredo, A.L. Atroch, R, Lopez. R.N.V. de Cunha, P.C. Teixeira. 2013. Heat-treatment and germination of oil palm seeds (Elaeis quineensis Jacq. Journal of Seed Science, 35(3):296-301.

Jimenez, V.M., E. Guevara, J. Herrera, R. Alizaga, F. Bangerth. 2008. Changes in hormone concentrations during dormancy release of oil palm (Elaeis guineensis) seeds. Seed Sci. \& Technol., 36: 575-587.

Kamil, J. 1979. Teknologi Benih. Angkasa Raya, Padang.

Kwon, H.J., S. L. Shin, Y.R. Kim, S.Y. Kim. 2020. Effect of temperature, gibberellic acid, and $\mathrm{KNO}_{3}$ treatments on seed germination of the wild plant Maesa japonica. Seed Science and Technology, 48(1):65-72.

Martins, C.C., L. Marilene, A. Bovi, J. Nakagawa. 2003. Desiccation effects on germination and vigor of King palm seeds. Horticultura Brasileira, 21 (1):88-92. 
Martine, B.M., K.T. Hilaire, K.K. Mongomake, K.K. Roger, K.K. Eugene, K.Y. Justin. 2011. Effect of the hydrogen peroxide treatments on germination of oil palm (Elaeis guineensis Jacq.) seeds. International Journal of Agricultural and Food Science, 1(3): 58-65.

Nazario, P., S.A.N. Ferreira, E.E. L. Borges, P.R. Genovese-Marcomini, M.S. de Mendoca. 2013. Anatomical and histochemical aspects of the peach palm (Bactris gasipaes Kunth) seed. Journal of Seed Science, 35(2):171-178.

Norsazwan, M.G., A.B. Puteh, M.Y. Rafii. 2016. Oil palm (Elaeis quineensis Jack.) seed dormancy type and germination pattern. Seed Science and Technology, 44(1): 15-26.

Norsazwan, M.G., U. R. Sinniah, A.B. Puteh, P. Namasivayam, M. Mohaimi, I.A. Amin. 2020. Temperature fluctuation improves oil palm (Elaeis quineensis Jack.) dura $\mathrm{x}$ pisifera seed germination. Seed Science and Technology, 48(1):49-55.

Nuraini. A., A. Pangaribuan, C. Suherman. 2016. Pemecahan dormansi benih kelapa sawit dengan metode dry heat treatment dan pemberian giberelin. Agrin, 20(2): 99-106.

Oliviera, T.G.S., A.G.R. Junior, P.P. de Souza, L.M. Ribeiro. 2013. Use of phytoregulators in overcoming macaw palm seed dormancy. Acta Scientiarum. Agronomy, 35(4): 505511.

Pan, C., S.W.E. Tan, J.W.H. Yong, L. Ge. 2017. Progress and development of analytical methods for gibberellins. Journal of Separation Science, 40(1): 346-360.

Polhaupessy, S. 2014. Pengaruh konsentrasi giberelin dan lama perendaman terhadap perkecambahan biji sirsak
(Anonna muricata L.). Biopendix, 1(1): 71-76.

Purbojati, L \& F.C. Suwarno. 2006. Studi alternatif substrat kertas untuk pengujian viabilitas benih dengan metode uji di atas kertas. Bul.Agron., 34(1): 55-61.

Rusmin, D., F. C. Suwarno dan I. Darwati. 2011. Pengaruh pemberian $\mathrm{GA}_{3}$ pada berbagai konsentrasi dan lama imbibisi terhadap peningkatan viabilitas benih purwoceng (Pimpinella pruatjan Molk.). Jurnal Penelitian Tanaman Industri, 17(3): 89-94.

Sedayu, B.B., J. Basmal, B.S.B. Utomo. 2013. Identifikasi hormon pemacu tumbuh eksrak cairan (SAP) Eucheuma cottoni. JPB Kelautan dan Perikanan, 8(1): 1-8.

Sudsiri, C., J. Nattawat, J. Kongchana, R.J. Ritchie. 2016. Effect of magnetically treated water pn germination and seedling growth of oil palm (Elaeis guineensis). Seed Sci. \& Technol., 44(2):267-280.

Tabi, K.M., G.F.N. Ebongue, G.N. Ntsomboh, Y. Youmbi. 2017. Effect of dry heat treatment along with some dormancy breaking on oil palm seed germination. South African Journal of Botany, 112: 489-493.

Tamrin, K., Setiawan, W.A. Setiawan, Ardian, A. Ridwan. 2017. Peningkatan Daya Kecambah Benih Sawit dengan Perlakuan Mekanis. Laporan Penelitian Grant Riset Sawit. Badan Pengelola Dana Perkebunan Kelapa Sawit, Kementerian Keuangan.

Tuan, P.A., R. Kumar, P.K. Rehal, P.K. Toora, B.T. Ayele. 2018. Molecular mechanisms underlying abscisic acid/gibberellin balance in the control of seed dormancy and germination in cereals. Frontiers in Plant Science, 9: 668 . 
p-ISSN: 1410-0029; e-ISSN2549-6786

Agrin Vol. 24, No. 1, April 2020

Widajati, E., E. Murniati, E.R. Palupi, T. Kartika, M.R. Suhartanto, A. Qadir.

Benih. Departemen Agronomi dan 2012. Dasar Ilmu dan Teknologi 